\title{
Considerații asupra teoriei bazei de articulație (I)
}

\author{
Enikő Pál ${ }^{1 *}$, Francisc Gafton ${ }^{2}$ \\ ${ }^{1}$ Facultatea de Științe Economice, Socio-Umane și Inginerești, Universitatea Sapientia, Piața Libertății 1, 530104 \\ Miercurea Ciuc, România \\ ${ }^{2}$ Facultatea de Litere, Universitatea „Alexandru Ioan Cuza", Bd. Carol I 11, 700506 Iași, România
}

\author{
Despre articol \\ Istoric: \\ Primit 19 mai 2016 \\ Acceptat 24 mai 2016 \\ Publicat 1 august 2016 \\ Cuvinte-cheie: \\ lingvistică diacronică \\ schimbare lingvistică \\ bază de articulație \\ bază psihologică \\ evoluție în limbă
}

\begin{abstract}
Rezumat
Prezentarea de față își propune să observe eforturile făcute în lingvistică spre a afla dacă baza de articulație este un concept viabil, util și dacă-mai presus de orice-reflectă realitatea. Întrucît, după știința noastră, cea mai bună dezvoltare a conceptului se petrece în spațiul științific românesc, prin A. Philippide și G. Ivănescu, vom încerca să urmărim direcția deschisă la mijlocul secolului al XIX-lea, sub influența perspectivei evoluționiste, și urmată de către cei doi mari teoreticieni ai conceptului.

În partea a doua a studiului nostru vom încerca o sinteză a chestiunii, din perspectivă actuală, mai cu seamă întrucît, după cei doi învățați români, lingvistica românească nu s-a mai ocupat de acest concept, deși premisele existente sînt solide, valoroase, adică de mare sprijin.
\end{abstract}

\begin{abstract}
„După modul cum vorbesc franțuzește mai mulți oameni vei cunoaște că unul este Francez de naștere, iar altul Romîn, altul Neamț, altul Englez" „în gura unui Romîn care vorbește franțzește nu atît limba romînă se schimbă după cea franceză, cît cea franceză după cea romînă
\end{abstract}

(Philippide, 1894)

\section{Preliminarii}

Încă de la începuturile științei lingvisticii istorice, înțelegînd caracterul procesual-istoric al limbii, lingviștii au încercat să afle principiile de la baza acesteia, spre a-i înțelege natura. Descoperirea faptului că limba se află într-o continuă mișcare și devenire a făcut ca atenția și energiile lingviștilor să fie atrase de căutarea cauzelor schimbării lingvistice, în general, și ale celor fonetice, în mod particular, eforturile de deslușire a acestei chestiuni fundamentale conducînd la felurite observații și teoretizări. Precum în cazul urmăririi oricărui tip de evoluție, constatarea empirică a schimbării, a transformării, a devenirii atrage în mod necesar după sine cel puțin trei întrebări importante: care sînt cauzele schimbării?; de ce se petrece acest proces în anumite direcții, iar nu în altele? și de ce se petrec schimbările majore în anumite perioade, iar nu în altele?

Impulsul consistent generat în lingvistică de gîndirea lui W. von Humboldt, valorificat prin contribuțiile unor savanți precum Fr. Bopp, A. Schleicher, H. Osthoff, K. Brugmann, A. Leskien, B. Delbrück, E. Sievers, W. Scherer, a condus la amplificarea studiului empiric-inductiv al limbii, din perspectivă istorică, în conjuncție cu teoria evoluționistă și cu curentele filozofice ale epocii. Acest proces va oferi temeiuri teoretice solide, la care se vor adăuga noi reflecții și mai ales material argumentativ, conducînd la edificarea unei concepții asupra evoluției limbilor, cu proiecții asupra cauzelor schimbării în limbă. Întregul complex de cunoștințe va fi apoi amplificat și aprofundat în sinteze teoretice care prezintă din perspectivă psihologică și biologică cauzele schimbării în limbă (Wechssler, 1900; Ginneken, 1933), iar din perspectivă istorică și interacțională desfășoară, în tratate exhaustive, istoria limbilor și a neamurilor (Philippide, 1927) sau extrage concluzii teoretice de mare generalitate, arătînd și explicînd argumentat modalitățile în care funcționează aparatul fonator și în care evoluează sistemele fonetice ale limbilor (Grammont, 1933).

\footnotetext{
*Adresă de corespondență: enikopaldr@gmail.com.
} 


\section{Baza de articulaţie. Problemele conceptului și ale termenului}

Încercînd o abordare inductivă a chestiunii, indo-europeniștii și romaniștii au căutat să afle cauzele diferențierii limbilor, sau pe cele care au dus latina populară către mai multe fizionomii, adică la mai multe sisteme lingvistice (întocmai precum au căutat naturaliștii originea speciilor). Ei au avut în vedere cauze interne și externe limbii, felurite modalități de diferențiere, diferențele dintre stadiile în care se afla stratul la momentul impunerii sale, cele dintre fondurile autohtone peste care s-a suprapus stratul, precum și pe cele dintre superstraturile ce-au acționat asupra limbilor în discuție. Dincolo de aceasta, însă, unii lingviști şi filosofi ai limbajului au căutat cauzele profunde ale schimbării lingvistice, observînd fenomenele de la nivelul limbilor şi examinînd acțiunile petrecute la nivel profund și esențial.

Deși erau humboldtieni și credeau în ideea modelării limbii de către spirit pînă într-atît încît limba ar reflecta spiritul unui neam, prin concepția lor, neogramaticii aveau datele necesare pentru a înțelege caracterul real și eficient al implicării factorului fizic în schimbările lingvistice. Mai mult, fiind interesați cu deosebire de prefacerile de la nivel fonetic, înțelegeau că acestea erau determinate în mod direct de factori și condiții de natură fizică.

Primele eforturi au mers în direcția teoretizării. Deținînd doar date empirice provenite din observații sporadice lipsite de control științific și o concepție lingvistică în curs de a se contura, dar mai ales întemeindu-se pe concepția lor filozofică asupra realității, erudiții și savanții primei perioade fac felurite considerații care aveau a lămuri mai degrabă speculativ un concept nebulos și greu de surprins prin metodele şi cu instrumentele ştiințifice existente. Căutînd un concept care să reflecte o realitate încă insuficient intuită și cugetată, spre a o înțelege lămurit, a o descrie și demonstra ${ }^{1}$, ei creează termeni precum Artikulationsbasis (F. Franke) și Operationsbasis (E. Sievers); alături de aceștia mai apar: Artikulationsweise, Indifferenzlage, Indifferenzzustand, Ruhelage, Ruhezustand, Normalstand (cf. Kedrova \& Borissoff, 2013). Dacă prima serie de termeni avea în vedere baza de articulație ca ansamblu specific și general, la un neam, de dispunere și funcționare a organelor vorbirii', cea de-a doua are în vedere baza de articulație ca: a) 'poziție neutră sau/și de repaos a organelor articulatorii'; b) 'cea mai comodă poziție pentru (a începe) articulare (a)'; c) 'direcție generală a mișcărilor, din cadrul procesului de articulare'; d) 'sumă a mișcărilor articulatorii dintr-o limbă etc. Prima serie pare a reflecta continuarea preocupării pentru esențele căutate de către neogramatici, cea de-a doua pare a privi la organele concrete în procesul de articulare (mai cu seamă limba), dar este atentă atît la termen ${ }^{2}$ (care, luat în sine, reflectă mai degrabă aspectul static decît pe cel dinamic), cît și la integrarea observațiilor în contextul teoretic al reflecțiilor asupra limbii.

Prima direcție este mai cu seamă teoretico-speculativă și caută cauzele, dar este mai degrabă lipsită de aparatul argumentativ, pe cînd cealaltă caută, cu paşi mici, efectele, observă comportamentul realităţii şi vrea să înţeleagă natura relaţiilor dintre structură și funcționare. Avînd a explica stări şi procese fundamentale din constituirea, existența și devenirea limbilor, acest concept trebuia să treacă prin procese de lămurire, spre a se elibera de zgura subiectivismului, a speculației și deductivismului, spre a căpăta soliditatea dată de dovada întemeiată pe observație, experiment și inducție. Prin cea de-a doua direcție, acest ocol parcurge calea utilizării efective a conceptului, de pildă în procesul de predare a limbilor străine, înglobînd și datele oferite de teoriile referitoare la baza percepției - arie, desigur, extrem de bogat

\footnotetext{
${ }^{1}$ O prezentare a acestor strădanii apare în Philippide (1914, 1927); Ivănescu (1980, 1984); a se vedea și Borissoff (2011).

${ }^{2}$ Indiferent de gradul de conturare și de limpezime a conceptului, sintagmele care au încercat a-l reda nu au fost niciodată îndeajuns de satisfăcătoare, diferențele dintre concepțiile asupra limbii și cele dintre perspectivele privitoare la schimbarea lingvistică generînd modalități diferențiate de abordare a fenomenului. Mai importantă decît consecința diversității terminologice „bază de articulare” (F. Franke), „bază de operare” (E. Sievers), „spiritul limbii” (K. Vossler), „predispoziții diferite” (F. de Saussure), „geniul limbii” (B.P. Hasdeu), „material apercepător” (Philippide) a fost cea de conținut, adică de înțelegere a conceptului, cu efecte asupra discuțiilor întîmpinătoare, a tratării acestei chestiuni și a aspectelor lingvistice care o implicau în vreun fel. Pentru bogata istorie a încercărilor de limpezire a conceptului, a căutărilor celui mai potrivit termen și a numeroaselor observații însoțitoare procesului, a se vedea Borissoff (2011), Dresher (2016), Dressler (1976), Hinde (1977), Jakobson (1973), Jenkins (1999), Jenner (2001), Koerner (2004), Lenneberg (1971). Pentru discuții asupra opțiunilor între „basis of articulation” și ,articulatory setting”, a se vedea Borissoff IATEFL; Jenner (2001).
} 
reprezentată bibliografic.

Lingviștii influențați de metoda experimentală a lui Claude Bernard, de pozitivism și de concepția evoluționistă au înțeles necesitatea de a așeza cercetarea sub rigorile empirice și experimentale ale inducției conjugate cu deducția, pentru a edifica teorii în consecință, dacă era cazul corectînd viziunea filozofică. Ei și-au asumat necesitatea ca observaţiile sau intuiţiile exprimate sub formă de teze să fie urmate de corelarea a nenumărate observații și date furnizate de experimente controlate, continuînd prin supunerea acestor rezultate la procesele gîndirii logice, pentru a ajunge apoi la concluzii teoretice, validate atît de realitate, cît și de judecăți științifice. Totodată, ei au înțeles că știința este cumulativă și (auto)critică, ea selectînd ideile demonstrate prin dovezi materiale și sprijinite de judecata logică, dar verificînd în mod necesar și constant atît edificiul deja construit, cît și elementele ce tind a-l compune. Deși anevoioasă—datorită decalajului dintre dinamica ideilor și a capacităţilor de demonstrare științifică a acestora, fiecare epocă fiind mai mult sau mai puțin lipsită de metodele și de instrumentele necesare verificării observațiilor și ideilor care, în mod natural, întrec mijloacele—, această cale reprezintă la modul optim procesul științific eficient.

\subsection{Baza de articulație - conformație a organelor articulatorii}

Deși așeza spiritul la baza existenței şi evoluției realității, identificînd cauzele cu principiile şi socotind că limba se adaptează la spirit și îl reflectă, A. Philippide vede în baza de articulație cauza adevărată și profundă a schimbării lingvistice, la nivel fonetic. Pe măsură ce reflectează asupra bazei de articulație și examinează—sub aspectul structurării, funcționării, relaționării și devenirii-formele de existență ale realității desemnate, lingvistul român își nuanțează, aprofundează și consolidează teoria. El va ajunge la o concepție coerentă asupra bazei de articulație și va încerca să fixeze conceptul și sintagma purtătoare, prin definiție, explicare, ilustrare şi folosire efectivă. La început, prin bază de articulaţie A. Philippide înțelege conformația organelor articulatorii, incluzînd deprinderile de articulare înnăscute și transmise din generație în generație (Philippide, 1914), apoi consideră că baza de articulație devine sub influența mediului - înțeles în sens larg-, mai ales prin contact lingvistic, limba adaptîndu-se la baza de articulație care aduce limba în existență fonică. Așadar, interacțiunea cu mediul și funcționarea bazei de articulație constituie cauza de schimbare a bazei de articulație, la rîndul ei, cauză a schimbărilor lingvistice la nivel fonetic (Philippide, 1927). Cum se observă, învăţatul român consideră interacțiunea cu mediul ca principalul factor ce determină complexul fizic reprezentat de conformația organelor articulatorii (baza de articulație).

În vremea lui A. Philippide, B. de Courtenay considera că mediul (condițiile fizice și geografice) își exercită influența asupra constituției organice a locuitorilor, cu consecințe asupra felului limbii acestora. La rîndul ei, o dată formată, limba influențează constituirea organelor vorbirii și fizionomia indivizilor, conjuncția dintre condițiile fizice și specificul dezvoltării limbii făcînd ca limbile să tindă spre folosirea preponderentă a anumitor părți ale aparatului fonator sau ale limbii ${ }^{3}$. Fără a defini baza de articulație, B. de Courtenay operează cu conceptul, considerînd că se referă la un rezultat comun membrilor comunităţii întrucît decurge din activitatea lingvistică în cadru social, și arată că deprinderile sînt naturale și inconștiente, exercițiul social prin imitație ținînd baza de articulație într-o stare stabilă. Totodată, el evidențiază faptul că variabilitatea acesteia constituie forța motoare a schimbării sunetelor, forța centripetă fiind „slabă” (apud Kedrova \& Borissoff, 2013). Reticent față de anumite chestiuni și perspective, mai ales cînd nu

\footnotetext{
${ }^{3}$ Perspectiva evoluționistă a lui Baudouin de Courtenay îl face să observe că tranziția de la stadiul de animal la cel de om dotat cu limbaj vocal-articulat privește trecerea de la modalitatea de eliberare a sunetului imitativ, din cavitatea laringală în cea bucală (apud Kedrova \& Borissoff, 2013), fapt care poate fi confirmat de cercetările care arată relația dintre vorbire și bipedalism (Falk, 1975, 2009).
} 
întrevede soluții și imaginează consecințe, F. de Saussure pomenește despre influența mediului, dar în chip cu totul vag. Plasat într-o perioadă în care chestiunea depășise stadiul afirmațiilor neargumentate, venind din raționamentele teoretice și concepțiile generale ale autorilor, G. Ivănescu examinează factorii care determină constituția diferită a organelor articulatorii la diferite neamuri și observă, în legătură cu efectele climatului, că unele particularități de funcționare ale plămînilor şi ale coardelor vocale se pot explica astfel ${ }^{4}$.

De altfel, ca urmare a gîndirii filozofice şi științifice a secolelor al XVII-lea și al XVIII-lea, în special după Lamarck și Claude Bernard, mediul începe a fi înțeles tot mai mult ca avînd un rol fundamental și determinant în desfășurarea evoluției, în general - concepție aplicată și în artă (H. Taine).

Totodată, admițînd că sunetele sînt determinate de elementele de conformație ale instrumentului care le produce, rezultă implicit că sunetele vorbirii sînt determinate de conformația organelor articulatorii. De aici decurge în mod consecvent că o schimbare de la nivelul organelor articulatorii poate atrage după sine o schimbare la nivelul sunetelor produse de respectivul complex organic ${ }^{5}$. Trăsăturile primare și fundamentale din domeniul fonetic al unei limbi fiind generate de baza materială a limbii, înseamnă că în schimbarea conformației organelor articulatorii trebuie căutate cauzele schimbării sunetelor vorbirii. $\mathrm{O}$ dată stabilită această intercondiţionare între felul și dispoziția organelor articulatorii (baza de articulație) și felul sunetelor produse de acestea și, în consecință, între schimbarea bazei de articulație și schimbările fonetice, rămîn de căutat factorii care contribuie la o anumită conformație a organelor articulatorii și la schimbarea ei în anumite direcții.

Desemnînd starea, firea și dispoziția organelor articulatorii, baza de articulație, element care gestionează producerea materialului lingvistic perceptibil, constituie cauza directă a configurației funcționale a sistemului fonetic la un moment dat, precum și a schimbării sunetelor, în vreme ce complexul afectivvolițional, cultural-spiritual și intelectual-mentalitar, baza psibologică, este responsabil de întrebuințarea şi orînduirea materialului produs. Efectele acțiunii primului aspect pot fi surprinse, cu precădere și în mod direct, în domeniul fonetic al limbii, ale celui de-al doilea apărînd îndeosebi în domeniile lexical, sintactic şi morfologic. Cum omul, însă, nu poate fi separat în ființă pur fizică, pe de o parte, și în entitate pur psihică, de cealaltă, tot astfel nici bazele limbii nu există și nu funcționează net distinse una de cealaltă, relația dintre ele fiind organică și inextricabilă. Chiar dacă are o componentă biologică, limba constituie un sistem relativ autonom, structurat în chipul său, cauzele evoluției ei nefiind deplin separate conform surselor structural-funcționale, ele decurgînd parțial și din chipul în care se orînduiește și funcționează sistemul limbii. A. Philippide înțelege că, la nivelul structurilor și funcțiilor ei, limba-produs al ființei umane sociale-poartă amprenta dublei determinări a condiției umane, în care latura fizică (materială) și cea psihică (spirituală) se întrețes, constituind laolaltă ceea ce s-ar putea numi „moment biologic” (Philippide, 1927).

Admiţînd existența bazei de articulație—conformație a organelor articulatorii, care determină felul sistemului fonetic al unei limbi și care variază în funcție de unele determinări dinspre mediul fizic de existență al diferitelor comunități-, rămîneau de explicat condițiile în care această bază, în anumite etape ale dezvoltării limbii, acționează mai puternic și mai rapid asupra limbii, pricinuind schimbări majore în limbă, față de etapele de relativă stagnare a acesteia. Căci în viața fiecărei limbi există epoci de rapidă dezvoltare lingvistică care înregistrează transformări calitative majore, dar și epoci de oarecare stabilitate.

\footnotetext{
${ }^{4}$ „În ținuturile cu o climă aspră, fie de stepă, fie polare, s-au dezvoltat sunete laringale sau glotale”, pe cînd „în ținuturile cu climă dulce, ca cea mediteraneană sau cea oceanică, laringalele nu s-au putut dezvolta sau au dispărut”. În orice caz, spune autorul, ,adaptarea organelor articulatorii la mediul fizic, în general respinsă de lingviști, nu poate fi tăgăduită” (Ivănescu, 1984). $\mathrm{Cu}$ inerentele decalibrări, date mai ales de dificultăţile unei astfel de cercetări, corelațiile acestea, avînd temeiuri în relația dintre viețuitoare și mediu, apar atît la biologi, cît și la lingviști, dar lipsa cercetărilor metodice, comune și/sau coordonate, lasă loc multor carențe.

${ }^{5}$ Dată fiind relația organică dintre compartimentele sistemului limbii, schimbările de la nivel fonetic pot afecta, în diferite grade, dar consecvent, toate subsistemele limbii.
} 
S-a observat și enunțat relativ devreme că schimbările pot decurge din simplul exercițiu al limbii dea lungul generațiilor, dar și ca urmare a contactelor cu alte limbi. În primul caz avem a face cu evoluția firească—din sînul aceluiași neam, care nu suferă vreo influență consistentă sau covîrșitoare, prin amestec și presiune, din partea altuia-, acționînd lent și producînd modificări mici și de rang scăzut, în procesele de utilizare a limbii și de trecere a limbii din generație în generație. Schimbările suferite de baza de articulație în urma amestecului dintre neamuri sau prin schimbarea raportului cantitativ dintre tipurile umane care alcătuiesc un popor constituie adaptări ale limbii cuceritorilor la baza de articulație a cuceriților, fiind mult mai spectaculoase. În acest caz, contactul brusc scoate la iveală și pune în act contrastele, pune la încercare starea existentă, pe de o parte, iar de cealaltă poate reliefa brusc o stare arătată lent sau ascunsă de evoluția normală. Cel dintîi tip de proces este doar constatat și acceptat firesc și implicit de către A. Philippide, fără a fi special analizat ${ }^{6}$, el arătîndu-se interesat cu deosebire de schimbarea bazei de articulație în consecința amestecului dintre neamuri.

În realitate-exceptînd cazurile primelor comunităţi, cel puțin o vreme, pînă cînd amestecurile dintre acestea devin semnificative, și pe cele ale unor triburi actuale, pe cale de dispariție ca atare, izolate și neatinse de ceea ce numim civilizație - datorită modalităților natural-restructurante în care au evoluat grupurile umane, au trecut multe milenii de cînd nu se mai poate vorbi despre comunități „pure”. Precum în cazul altor domenii și obiecte ale cunoașterii, și aici există o tendință naturală, atît la nivelul cercetătorilor, cît și la cel profan, de a considera realitatea ca și cum ar fi dotată cu puritate, simetrie, echilibru, constante „perfecte”, trăsături ce lipsesc obiectelor și proceselor naturale (nici un corp, ceresc sau viu, nici o substanță anorganică sau organică, nici un fenomen natural nu sînt „perfecte”). Realitatea oferă întotdeauna entități „impure”. Chiar dacă, pentru procesul gîndirii, este mai lesne ca judecata să plece de la trăsături şi de la realităţi simple (în fapt, ipotetice și lipsite de corespondent întocmai), raţionamentul și rezultatele corecte sînt condiționate de înțelegerea și judecarea realităţii în datele ei reale. De aceea, nu numai că comunitățile nu pot fi considerate ca fiind pure în vreun moment al existenței lor, dar nici un presupus punct de plecare „pur” nu poate fi avut în vedere. Chiar simpla existență funcțională a unei entități a realității-în condițiile caracterului fundamental interacțional și dinamic al materiei vii-face ca regula firească să o constituie „amestecul”, cu ponderi diferite, al formanților ei (mai ales întrucît viața are ca atribute, condiții și efecte fundamentale și sine qua non interacțiunea și adaptabilitatea, în primul rînd la mediu). Dacă, înțelegînd acest fapt și căutînd comoditatea, se poate imagina că, în stadiul lor prim și iniţial, comunităţile sînt pure, ele trec destul de repede, inevitabil și irevocabil la stadiul de conglomerat de comunități, apoi la cel de conglomerat de conglomerate etc. ${ }^{7}$ Lucrul acesta, de altfel, împreună cu critica conceptului 'rasă', apare cu maximă limpezime în critica pe care o aduce A. Philippide teoriei lui K. Vossler (Philippide, 1927). La scara istoriei, indiferent de momentele de stabilitate, popoarele sînt, prin excelență, niște conglomerate de populații, așa cum celula vie este un simbiot care își datorează existența simbiozei mai multor entități ${ }^{8}$.

Pe de altă parte, faptul că diferitele comunităţi dispun de conformații diferite ale organelor ar-

\footnotetext{
${ }^{6}$ Pentru meritele indiscutabile ale lui Philippide în privința dezvoltării teoriei bazei de articulație, precum și pentru unele aspecte lejer diferite ale acesteia a se vedea Ivănescu (1984).

${ }^{7}$ Conviețuirea naturală este în mod firesc și legic asimilatorie, elementele cele mai eficiente pentru supraviețuirea în condițiile date fiind cele selectate. Abia eforturile conștient orientate în anumite direcții pot direcționa conviețuirea, stimulînd (dacă se referă la elemente care ar fi selectate în mod firesc) sau frînînd (cînd se referă la elemente care nu intră în sfera selecției naturale) procesele asimilatorii firești. Astfel s-au petrecut lucrurile și în cazul influenței civilizației și limbii latine asupra celor cuceriți: a) a funcționat asimilarea naturală (selectîndu-se deopotrivă elemente ale cuceritorilor şi cuceriților); dar în conjuncție cu b) stimularea procesului prin presiunea în favoarea unor elemente aparținînd cuceritorilor; și c) păstrarea unor elemente aparținînd cuceriților. Atît în b) cît și în c) era vorba, desigur, despre elemente neselectabile în mod natural.

${ }^{8}$ Cf. Wartburg (1962). Cercetări recente arată că, datorită dinamicii populațiilor și contextului interacțional existent între civilizații și culturi, se înregistrează o creștere sensibilă și inexorabilă, chiar dacă relativ „lentă”, a procesului de omogenizare a populațiilor, civilizațiilor și culturilor (Oliveira et al., 2006).
} 
ticulatorii, precum și că acestea funcționează în mod diferit, ține de condițiile diferite de mediu (și de tot ceea ce decurge aproape geometric din această diferență) și este observabil pe calea analizei lingvistice. Dincolo de unele remarci destul de subiective ale lui A. Philippide (făcute mai ales în Philippide, 1894, dar și în Philippide, 1927), G. Ivănescu face observații empirice care demonstrează relația dintre unele diferențe organice și funcționale, cu consecințele acestora 9 . Totodată, dat fiind caracterul implicit și fundamental al componentei materiale, anatomo-fiziologice a limbii, se înțelege că baza de articulație variază diacronic, la nivel de individ și de comunitate și că ea acționează permanent. Pe de o parte, întrucît nu există neamuri unitare, sistemul fonetic al unui neam trebuie considerat ca fiind rezultatul cumulării selective și reciproc ajustante a elementelor sistemelor în contact, ale comunităților alcătuitoare (Philippide, 1927; Ivănescu, 1984). Pe de altă parte, nici în cadrul aceleiaşi comunități nu se poate vorbi despre o identitate perfectă a bazei de articulație, privită în realitatea ei complexă. Este firesc ca, în cadrul unei astfel de comunități, să existe variații mai mari sau mai mici în ceea ce privește conformația organelor articulatorii și aptitudinile articulatorii (Philippide, 1927; Ivănescu, 1984). Dacă se are în vedere conglomeratul de comunități care alcătuiește un neam, unitatea aproximativă a limbii se poate datora nivelării, prin împrumut, a diferențelor care se produc de la un individ la altul sau de la o comunitate la alta (Philippide, 1927). Cu alte cuvinte, conviețuirea constantă în cadrul unui mediu comunitar normal (relativ închis) poate omogeniza diferențele antropologice dintre indivizi; deși cu mai multă anevoință, același lucru se petrece și într-un mediu deschis unde, însă, dinamica fiind ridicată, ea este compensată de presiunile de ordin social.

Pe această bază, A. Philippide explică nașterea limbilor romanice înainte de toate prin trecerea limbii latine de la baza de articulație latină la bazele de articulație proprii popoarelor cucerite, ceea ce a obligat latina să se adapteze la aceste noi baze de articulație. În opinia lui, această adaptare fonetică începe chiar din momentul contactului dintre popoare, concomitent cu amestecul etnic: „conformația deosebită a organelor vorbirii diferitelor popoare romanizate, a buzelor, a poziției limbii în stare de repaos, a cerului gurii, a vălului palatului, a nasului, a coardelor vocale, a trebuit să dea $o$ deviere imediată sunetelor limbii latine, care a condus la o schimbare repede a acestora" (Philippide, 1927), fiind, apoi, desăvîrșită după ce autoritatea statului roman și, prin aceasta, prestigiul limbii sale oficiale, limba latină, a încetat, adică după cucerirea Imperiului de către popoarele migratoare.

Dacă se consideră că baza de articulație denumește 'conformația organelor articulatorii', ca structură generată de condițiile de mediu, apoi determinată și lent ajustată deopotrivă de condițiile de mediu și de efectele exercițiului ei (mai puțin sau puternic afectat de contact), iar limba este rezultatul istoric și procesual al funcționării bazei de articulație, în condițiile enunțate (ale unui mediu fizic, biologic, social și lingvistic), atunci se înțelege că limba cuceritorilor este cea care,

\footnotetext{
${ }^{9}$ Elevul lui A. Philippide arată că unele vocale se regăsesc exclusiv sau preponderent la anumite comunități $(\ddot{a}, \ddot{o}, \ddot{u}$, caracteristice preponderent nordicilor, dalicilor sau falicilor; $\breve{a}$ și $\hat{\imath}$, caracteristice dinaricilor și anatolienilor, precum și mediteraneenilor din aceste regiuni). Tot conformația organelor articulatorii ar explica și corespondența dintre predispoziția către vocale velare rotunjite (labializate) și proeminența buzelor caracteristică dinaricilor și mediteraneenilor, sau relația dintre producerea consoanelor $k$ 'și $g$ 'și un canal oral mai strîmt - strîmtarea rezultînd fie din forma mai plată, mai puțin rotundă a palatului și a maxilarului superior, fie din volumul mai mare al limbii. Prin modul de funcționare al unor organe articulatorii s-ar explica apariția sau dispariția lui $h$ - prezența unui $h$ fonic se explică prin modul de funcționare a plămînilor (aspirații mai slabe sau mai puternice) - , iar apariția explozivelor aspirate se poate pune în legătură cu modul de funcționare a coardelor vocale etc. (Ivănescu, 1984). Un eventual dezacord cu explicațiile lui G. Ivănescu ar trebui urmat nu de negarea întregii explicații (care nu ar avea neapărat cauze în felul în care se desfășoară cercetarea științifică, ci mai cu seamă în concepția filozofică sau ideologică a preopinentului), ci de căutarea onestă a exemplelor și explicaţiilor corelate și corecte, abia negăsirea nicicum a acestora avînd a duce la respingere. Alături de acestea, G. Ivănescu face observații importante în legătură cu vocala și cu timbrul implicite, și cu poziția de repaos a organelor articulatorii (Stări și schimbări în legătură cu vocala implicită, în Ivănescu, 1983, p. 80-86; Timbrul vocalic implicit al consoanelor, în Ivănescu, 1983, p. 87-96; Constituirea unei fonetici care să nu fie fiziologie și acustică, în „Buletinul Institutului de Filologie Română «Alexandru Philippide» din Iași”, V, 1938, p. 55-139, republicat în Ivănescu, 1983, p. 219-319).
} 
deși se impune tuturor ca limbă, va suferi de pe urma influenței bazei de articulație a cuceriților, aceasta fiind cea care redă noua limbă, în chipul posibilităților ei. Este o situație tipică de asimilare, în care cuceritul nu dispare decît aparent, interacțiunea adaptativă neconstituind o formă de aneantizare, ci de reciprocă modelare. El constituie mediul care, prin particularitățile structuralfuncționale ale aparatului său fonator și în cadrul procesului de adoptare a materialului lingvistic adus (impus) de către cuceritor, va modifica materia furnizată de către acesta.

Precizarea, deosebit de importantă, este necesară întrucît adesea pare a fi scăpată din vedere, confuzia celor care se referă negativ la baza de articulație venind din neînțelegerea acestei distincții, operate de către A. Philippide, nu cu vigoarea necesară situațiilor de posibilă confuzie, dar clar reliefate de către G. Ivănescu.

Privitor la condițiile care au favorizat manifestarea bazelor de articulație ale limbilor cucerite și care vor ajunge să devină neolatine, Ivănescu (1980) are o opinie nuanţată. El socoate că, în adevăr, adaptarea unei limbi la o nouă bază de articulație nu se poate produce decît în decursul cîtorva secole. Admițînd că baza de articulație a unei limbi nu se poate manifesta oricînd-căci există o limitare în timp a efectelor acesteia-, savantul ieșean încearcă să găsească acele condiții care, în anumite răstimpuri, permit manifestarea ei, în vreme ce altele o împiedică. Potrivit acestuia, pe durata existenței Imperiului Roman, bazele de articulație (și cele psihologice) ale neamurilor din Imperiu nu s-au putut manifesta deoarece structura socială era astfel încît putea neutraliza diferențele, impunînd peste tot modelul propagat dinspre centrul de guvernămînt. În această epocă a stăpînirii romane, caracterizată printr-o intensă circulaţie a oamenilor (transportatori de bunuri, limbă, civilizație, mentalitate etc.), bazele de articulație nu s-au putut manifesta, fiindcă intensa circulație de la o regiune la alta avea printre efecte răspîndirea pe arii întinse a unei limbi comune și a normelor lingvistice comune. Trecerea de la economia de schimb la economia naturală din epoca medievală (cea feudală în Apus și cea a obștilor sătești în Răsărit), adică trecerea de la o viață orășenească intensă la o viață rustică, parțial de tip feudal, parțial de tip gentilic, este aceea care putea pune un obstacol în calea imitării idealului de limbă și a menținerii limbii comune, întrucît încetarea contactului strîns între regiuni a înlăturat și norma lingvistică cultă superioară, şi ,nimeni nu se mai străduia să vorbească altfel de cum putea” (Ivănescu, 1980). Destrămarea Imperiului și a autorității de stat romane a contribuit la apariția acestor schimbări în structurile sociale fundamentale, însă nu factorul politic, ci unul economic constituie adevărata condiție care a permis manifestarea bazelor de articulație, iar acest fapt economic constă, în opinia lui G. Ivănescu, în încetarea economiei de schimb și în intensificarea economiei naturale ${ }^{10}$.

Cu toate acestea, dacă se admite existența și acțiunea bazei de articulație, mijloacele fizice prin care acționează aceasta și caracterul ei imperios, este rezonabil să se presupună deopotrivă că: a) ea a acționat asupra latinei vorbite de către particularii (încă bilingvi sau interlingvi; cf. Selinker, 1972) din teritoriile cucerite; b) schimbările către care aceasta îndemna au putut fi frînate de forțele centripete ale ocupației romane, desigur, fără a avea vreo dovadă concretă și măsurabilă a gradului în care ar fi avut loc aceste procese. (Deși cuceritorul era latin, într-o anumită măsură, supusul era limba sa - de către baza de articulație.) Căderea Imperiului scapă frîu liber unei realități vechi, adică acțiunii bazei de articulație. Ceea ce se schimbă după căderea Imperiului este că: a) dispar forțele centripete, adică presiunea constantă a mediului latin; b) acțiunea bazei de articulație nu mai este constrînsă sau împiedicată în a-și exercita forța temperată de cîteva secole de presiune. După acest moment, însă, este la fel de rezonabil să se presupună că acțiunea bazei de articulație nu mai putea fi la fel de puternică precum ar fi fost în prima perioadă de

\footnotetext{
${ }^{10}$ În germene, fără contextualizare nuanțată, ideea apare la F. de Saussure, care arată că stabilitatea politică și instabilitatea nu influențează limba în același chip, echilibrul politic stabilizînd limba (încetinind mișcările), iar instabilitatea sporind variabilitatea și dinamica. Fixarea vremelnică, relativa stabilitate a unui idiom poate avea cauze externe (influența Curții, a școlii, a academiei, a scrierii), favorizate de echilibrul social și politic, în vreme ce accelerarea mișcărilor din limbă este consecința (nu exclusivă) a răsturnărilor de la acest nivel (Saussure, 1997).
} 
după cucerirea romană. Dacă baza de articulație este muabilă (căci nu poate fi imuabilă), dacă are capacitatea de a coevolua lent împreună cu sistemul fonetic pe care îl exprimă, dacă cele două se pot acomoda mutual (chiar admițînd că baza de articulație este mai „rigidă”, iar limba mai flexibilă și mai suplă), atunci rămîne de admis că multe dintre elementele sistemului cuceritor au putut ajusta baza de articulație, manifestările ei de după dispariția forțelor centripete modulînd doar unele aspecte ale sistemului cuceritor.

\subsection{Baza de articulație - set de deprinderi articulatorii}

Întrucît încă din vremea sa (dar şi după aceea, și chiar în zilele noastre), explicația prin baza de articulație a fost folosită, dar sintagmei i-au fost atribuite conținuturi convenabile mai curînd concepției diferiților lingviști decît consecvente cu teoria bazei de articulație, A. Philippide a oferit explicații privitoare la relația dintre baza de articulație și deprinderile date de folosirea limbii autohtone. Atît unele critici aduse teoriei sale, cît și unele încercări de explicare a unor situații concrete îi oferă prilejul unor precizări importante, evidențiind confuziile făcute de către critici - multe dintre acestea din urmă surprinzătoare întrucît încercau critica științifică a unui concept, dar fără grija pentru nevoia imperioasă de a opera cu rigoarea și precizia pe care le solicitau (Philippide, 1927).

Unul dintre aceștia era S. Pușcariu, care consideră că modul de rostire al vorbitorilor poate fi determinat nu de moștenirea bazei de articulație, ci de obişnuința cu anumite mişcări articulatorii.

În concepția lingvistului clujean, popoarele și-ar păstra vechile obiceiuri articulatorii după ce li se impune o nouă limbă. Astfel, din moment ce romanizarea nu a putut șterge toate urmele structurii psihice și fizice ale popoarelor autohtone, este de presupus că în rostirea limbii latine de către băştinași, deprinși cu alte articulații și coarticulații, „să se fi ivit unele potriviri la obiceiurile de rostire autohtone” (Pușcariu, 1994). În felul acesta, sunetele specifice fiecărei limbi romanice s-ar putea explica prin obişnuința indigenilor de a rosti acele sunete particulare. Totodată, S. Pușcariu este de părere că atunci „cînd poporul părăsește limba lui maternă, își pierde totodată și baza de articulație". În acest caz, el pleacă de la observarea unui tip aparte și diferit de situație (învățarea limbii române de către o minoritate care trăiește în sînul românilor), și face referire la situația obișnuită, în care copiii își învață limba de la părinți (Pușcariu, 1937, 1994).

Se pare că S. Pușcariu respinge definirea bazei de articulaţie ca fiind 'conformație a organelor articulatorii', afirmînd că se referă la 'deprinderi articulatorii', și neagă transmiterea genetică la nivel fizic (darwinist), afirmînd-o la nivel funcțional (lamarckist). Explicația transformării deosebite a limbii latine populare în noile limbi romanice exclusiv prin deprinderi articulatorii diferite în sine este în cel mai bun caz carențială, iar exemplul minorității (fie că este bilingvă, fie că se deznaționalizează) doar neagă existența bazei de articulație, dar nu demonstrează inexistența ei, plasînd deprinderile într-o sferă de acțiune nedemonstrabilă ${ }^{11}$. Cazul copiilor (supravegheați de către comunitate și complet supuși presiunilor sociale) nu este nici măcar comparabil cu cel al contactului prin cucerire.

A. Philippide atrage atenția asupra posibilităţii de confuzie a schimbărilor produse în limbă de modificările bazei de articulație—care este una permanentă—cu cele petrecute în procesul de adoptare a unei limbi noi. Influența limbii autohtone constă în păstrarea unor deprinderi din limba părăsită, în perioada acceptării unei alte limbi (care va deveni maternă $)^{12}$. Astfel, potrivit savantului român, în cazul influenței limbii autohtone asupra unei limbi nou adoptate nu este vorba despre modificările pe care un fizic și un psihic deosebite le produc în limba adoptată, ci de influența directă pe care limba părăsită a putut avea asupra limbii adoptate, adică abia aici avem a face cu deprinderi. Față de această situație, influența bazei de articulație și a celei psihologice nu presupune deprindere, ci schimbarea sunetelor limbii adoptate după firea fizică și psihică proprie vorbitorilor autohtoni. În procesul de adoptare a unei limbi noi, vorbitorul

\footnotetext{
${ }^{11}$ Acest tip de comportament apare des în cazul conceptelor respinse avînd în vedere note imaginare sau din afara științei, existența reală a unei entități în acel loc impunînd construirea unui alt concept ale cărui limite generează în mod necesar felurite carențe.

${ }^{12} \mathrm{La}$ rîndul său, G. Ivănescu atrage atenția asupra faptului că influența limbii autohtone asupra limbii cuceritorilor este „altceva decît manifestarea bazei de articulație” (Ivănescu, 1980).
} 
se poate dezvăța de sunetele pe care le producea, adoptînd sunetele limbii noi, eventual păstrînd unele deprinderi de care nu s-a eliberat, și care pot pătrunde în noua sa limbă, inclusiv sub forma unor sunete din limba veche. Acesta este felul în care se manifestă influența limbii autohtone asupra celei adoptate. Baza de articulație, în schimb, este cea care se face responsabilă atît de felul în care se adoptă sunetele limbii noi-adaptîndu-le după constituția fizică a vorbitorilor autohtoni-, cît și de felul sunetelor înseși din limba maternă dintre care unele se pot păstra și în limba adoptată (Philippide, 1927) ${ }^{13}$.

În concluzie, baza de articulație se referă la o realitate anatomo-fiziologică, și anume la conformația organelor articulatorii, în vreme ce deprinderea sau obişnuința se referă la efectele funcționării și ale exercițiului îndelungat al bazei de articulație, în anumite modalități (adică redînd un sistem fonetic dat și interacționînd cu acesta). Sînt două concepte, căci sînt două realități distincte cu două tipuri de efecte, A. Philippide arătînd cu limpezime: „Dacă te pui într-adevăr din punctul de videre al bazelor de articulație și psihologică, operezi numai cu materialul oferit de limba adoptată”, căci deprinderea sau obișnuința se referă la materialul limbii cucerite. De aceea, examinînd o întîmpinare a lui H. Schuchardt, care crede că evoluția $c t>p t$ trebuie pusă pe seama influenței limbii dace asupra latinei, A. Philippide se întreabă care este gîndul lui H. Schuchardt: a) dacii aveau un $c t$ care trecuse la $p t$, iar legea, fiind în vigoare la momentul contactului, a continuat să se aplice, ca deprindere, deopotrivă asupra materialului latinesc?; sau b) dacii aveau un $c t$ netrecut la $p t$, la acest material adăugîndu-l pe cel latin, după care s-a petrecut schimbarea fonetică? Exemplul arată cu destulă evidență că astfel de critici erau iscate de pozițiile teoretice ale celor implicați, iar contra-exemplele nu decurgeau din examinarea atentă a unei situații, după înțelegerea conceptelor în discuție, ci din susținerea unor convingeri bazate pe impresii sau pe o concepție generală despre lume.

\subsection{Baza de articulație și împrumutul}

În cadrul aceleiași discuții, A. Philippide consideră necesar a face o altă distincție, între modificările datorate bazei de articulație și cele rezultate ca urmare a împrumuturilor (Philippide, 1927) ${ }^{14}$. Distincția privește situațiile în care între diverse limbi se poate presupune un oarecare grad de înrudire - nu neapărat în sensul unei ascendențe comune, dar al prezenței unor caractere esențiale comune (de apartenență la același spațiu geografic, de cultură etc.). Recunoscînd primejdia arbitrariului în atribuirea unor fenomene fie influenței limbii autohtone, fie procesului de împrumutare din limbi vecine-dar care se înscriu întrun fond autohton mai larg căruia îi aparține și limba în cauză—, A. Philippide nu se arată încrezător în posibilitatea limpezirii lor și a stabilirii unor criterii pentru a distinge ceea ce, în acest caz, ar fi un împrumut. Mai mult, el constată cu prudență că, în asemenea situații, nu există vreun criteriu pentru a separa bazele de articulație (și psihologice) și moștenirea din limba autohtonă, pe de o parte, și împrumutul, de cealaltă. În aceste condiții se poate spune, cel mult, că ,împrumutul e cu atît mai puțin probabil, cu cît fenomenul e mai răspîndit și mai în detaliu răspîndit” (Philippide, 1927). De pildă, dacă un fenomen este răspîndit în toate limbile balcanice, poate avea temei îndoiala asupra faptului că acesta ar proveni dintrun împrumut plecat de la una din aceste limbi. Dimpotrivă, dacă un fenomen se regăsește doar în cîteva dintre aceste limbi, el nefiind prezent în majoritatea limbilor, atunci fenomenul în cauză poate fi pus pe seama împrumutării dintr-o limbă în alta (Philippide, 1927).

\footnotetext{
${ }^{13}$ Pentru chestiunea învățării unei limbi străine de către un adult și pentru posibilele avataruri prin care se trece cu acest prilej, cf. Selinker (1972).

${ }^{14}$ Prin imprumut, el înțelege aici nu atît împrumuturile făcute dintr-o limbă autohtonă într-una de curînd adoptată, cît mai degrabă pe cele operate din limbile vecine și contemporane cu cea în discuție (Ivănescu, 1984). Edificatoare, în acest sens, este și constatarea: „Numai atunci, cînd apar în limbă simboale (cuvinte și forme gramaticale), care nu se pot explica prin materialul limbii adoptate ori prin onomatopee și sunete reflexe, și pentru care n-ai nici un motiv de a presupune că s-ar datori moștenirii din limba autohtonă, dar care se găsesc ca ceva obișnuit și normal în limbi străine cu totul altele [s.n.], poți spune cu siguranță că acele simboale sînt împrumutate" (Philippide, 1927).
} 


\subsection{Baza de articulație - rezultanta interacțiunii organelor și a deprinderilor articulatorii}

A. Philippide atribuie conformației organelor articulatorii o importanță covîrșitoare, aproape exclusivă, în determinarea sistemului fonetic al unei limbi (Philippide, 1927). Concepînd lucrurile în aceeași direcție, G. Ivănescu aduce unele rectificări și completări. Potrivit acestuia, baza de articulație cuprinde și totalul de înclinaţii articulatorii, care, „deși sînt determinate în parte de conformaţia organelor articulatorii, se moștenesc și influențează direct asupra limbii” (Ivănescu, 1980) ${ }^{15}$. Altfel spus, baza de articulație este o anumită conformație a organelor articulatorii dimpreună cu acțiunea lor în rostirea limbii (materne). Această dispoziție și mișcările articulatorii care decurg din ea sînt necesare exprimării firești în acea limbă. De aceea, baza de articulație este fundamentul determinant (nu exclusiv și deplin) al sistemului fonetic al limbii, iar într-un moment următor este rezultanta respectivei structuri funcționale (Honikman, 1964). Deprinderile sînt articulațiile (care se concretizează prin sunete) ce se constituie în exercițiul firesc al acelei limbi, în procesul de coarticulare a sistemului fonetic respectiv. Cu timpul, deprinderile articulatorii se fixează, devin înnăscute și se pot transmite de la o generație la alta, ajungînd să constituie specificul articulatoriu al unui individ sau unei colectivități. Atît organul, cît și produsele acestuia constituie realități dinamice și interacționale, care coevoluează (Honikman, 1964; Oyama, 2015).

\section{Obiecții și observații la teoria bazei de articulaţie}

Chiar dacă elementele teoriei bazei de articulație au putut fi adoptate și perpetuate prin uz, mai cu seamă în ceea ce privește manifestarea în limbile romanice a unor particularități de rostire autohtone, miezul tezei, precum și multe aspecte și elemente componente au rămas insuficient observate, discutate și demonstrate. Așa cum se petrece în numeroase situații în care se încearcă edificarea de teorii științifice care să explice fenomene complexe, ierarhizate, interconectate cu altele în cadrul unei realități avînd o devenire complexnuanțată, pe lîngă dificultățile inerente unor astfel de întreprinderi, se ivesc deîndată calculele ideologice care pun în act instrumente neștiințifice - în primul rînd prin chiar faptul de a anticipa, prevedea și întrezări consecințele unui fenomen încă necunoscut. Lucrul acesta se petrece mai cu seamă atunci cînd teoriile au implicații nu doar în plan strict științific, dar și-cel puțin în viziunea și din perspectiva unor gînditori care pleacă de la postulate sau axiome-implicații colaterale de ordin ideologic sau mentalitar (cazul teoriei evoluționiste, al fizicii relativiste, al celei cuantice etc.). În acest caz, aproape concomitent cu răspîndirea teoriei apar și obiecțiile mai mult sau mai puțin vehemente împotriva ei.

Rezervele față de teoria bazei de articulație ${ }^{16}$ nu se datorează doar faptului că nu toți o înțeleg întocmai. Prima mare cauză de ordin general zace în centrarea pe o anumită perspectivă, cu excluderea sau minimalizarea celorlalte și în ierarhizarea greșită a principiilor, metodelor de cercetare și a faptelor din realitate. Aici se află criticile obiective și necesare, întrucît au în vedere clarificarea trăsăturilor esențiale, înlăturarea impreciziilor, degajarea conceptului din masa intuițiilor și a observațiilor din care a apărut, apoi testarea naturii, limitelor și operativității sale. Marele neajuns este că, îndeobște, se pleacă de la anumite concepții filozofice, sub al căror imperiu stau interpretările ce guvernează înțelegerea. Totuși, astfel de observații oferă darul prețios de a îndemna la intensificarea cercetării în două direcții, una fundamentală, care privește descifrarea aspectelor realității premergătoare-care determină și la care este conectată presupusa realitate la care se referă conceptul一, precum și a aspectelor ce țin de funcționarea sa integrată, a efectelor existenței sale active și a eventualelor derivate ale sale, și una specială, care se referă la lămurirea în sens științific a conceptului astfel observat și cugetat. A doua cauză decurge din perspectiva orientată de felurite concepții sau idei din afara științei. Aici se adună obiecțiile generate de atitudinile obișnuite la cercetătorii care nu reușesc să accepte sau să înțeleagă alte perspective de structurare a realității (științifice) decît cele proprii

\footnotetext{
${ }^{15} \mathrm{G}$. Ivănescu argumentează afirmația prin fapte precum articularea lui $h$ sau lipsa lui, respectiv tendința de a pronunța pe $s$ intervocalic ca $r$, care, în opinia sa, nu se pot explica prin conformația organelor articulatorii, ci numai prin obișnuințe articulatorice înnăscute (Ivănescu, 1980).

${ }^{16}$ Pentru cei care, pînă în primul sfert al secolului trecut, s-au pronunțat în contra bazei de articulație, respectiv pentru argumentele aduse de aceștia, a se vedea Philippide (1927).
} 
sau care par a nu încorpora viziunile și dezideratele mentalitare ale societăţii, la care ei au aderat sau pe care le predică.

În măsura în care permit cercetării să ofere argumentat răspunsurile științifice solicitate, ambele categorii de observații pot fi benefice. Totuşi, încă dinainte de consolidarea existenței conceptului 'bază de articulație', cel de-al doilea tip de obiecții a conotat negativ conceptul, exclusiv prin simple afirmații și prin procedeul asocierii conceptului (care ar fi trebuit mai întîi înțeles şi lămurit) cu altele negative, stimulînd trecerea atributelor celor din urmă asupra celui dintîi. În felul acesta au fost serios obstrucționate cercetările care aveau a prezenta atributele și utilitatea conceptului 'bază de articulație', fapt comis fără ca reiterarea și augmentarea acuzelor să fie însoțite de vreun argument. Prea atenți la implicațiile intuite sau presupuse la o primă privire, unii resping doar termenul sau/și teoria, alții deformează chestiunea sau o eludează, în vreme ce alții încearcă să o înțeleagă pentru a afla dacă poate fi folosită în vreun fel, în vreme ce alți cîțiva încearcă să construiască raționamente sofistice prin care să nu respingă în mod neștiințific o teorie luată în seamă pentru valoarea sa științifică, dar nici să accepte o teorie respinsă pentru presupuse vini ideologice, în cele din urmă înlăturînd-o (Saussure, 1997; Coșeriu, 1992).

3.1. W. Meyer-Lübke ridică obiecția că pronunțiile latinei, pe baza articulațiilor proprii neamurilor romanizate, sînt aproape imposibil de probat prin fapte (Philippide, 1927). Principial, acest tip de obiecție este important, chiar dacă - mai ales în cazul special al limbilor romanice-pronunțiile latinei populare pot fi reconstruite pe temeiuri de oarecare încredere. De asemenea, nu se poate nega că limbile autohtone au exercitat o anumită influență, fiind evident că prefacerile fonetice proprii fiecărei limbi romanice au printre surse fondul autohton guvernat de baza de articulație. Lingvistul elvețian pune deosebirile dintre limbile romanice pe seama stării diferite a latinei din timpurile cînd aceasta a fost introdusă în diferitele provincii și mai ales pe socoteala obstacolelor care au împiedicat contactul de la o regiune la alta. În schimb, el nu ia în seamă faptul că starea deosebită a limbii latine s-ar putea datora tocmai amestecului diferit de popoare și că deosebirile etnice sînt în relație cu bazele de articulație diferite, așa cum arată Philippide (1927).

3.2. O altă critică formulată la adresa bazei de articulație privește capacitatea unui individ, a oricărui individ, de a rosti orice sunet al vorbirii și de a vorbi orice limbă, indiferent de conformaţia organelor articulatorii cu care se naște. F. de Saussure, de pildă, susține că aparatul fonator nu variază de la o rasă la alta, nu mai mult decît de la un individ la altul, și oferă exemplul africanului născut în Franța care vorbește la fel de bine limba franceză precum francezii indigeni. (O poziție asemănătoare adoptă S. Pușcariu, care aduce în discuție situația germanilor care poartă nume franțuzești sau cea a sașilor românizați.).

Probabil că dintre toate considerațiile la adresa teoriei bazei de articulație, aceasta este cea mai lipsită de temei deoarece este singura care se referă la ceva care nu se află nicicum în sfera la care se referă această teorie. Întîmpinarea lui F. de Saussure arată că obiecțiile nu ar trebui să încerce spulberarea unor încercări de aflare a adevărului, ci să concure la aflarea acestuia, un gînd stîrnit de o teorie, înainte de a se așeza pe poziții contradictorii, avînd mai degrabă a căuta să afle cum este de fapt realitatea.

Teoria bazei de articulație nu susține imuabilitatea sau ierarhizarea a ceva. Dimpotrivă, înțelegînd că există un punct de plecare avînd o anumită natură, anumite caracteristici și efecte, teoria arată că dacă alogenul nu poate articula precum băștinașul timp de cîteva generații, faptul se datorează bazei de articulație, și că, apoi, cînd va reuși, faptul se va datora dobîndirii deprinderilor necesare, iar în cele din urmă schimbării bazei de articulație. Pe de o parte, lingvistul ieșean observă că fenomene precum cele semnalate de către F. de Saussure și S. Pușcariu se găsesc la tot felul de limbi și popoare, și mai ales că, rămînînd în comunitate de-a lungul timpului, străinii pot dobîndi pe deplin pronunțarea poporului a cărui limbă o adoptă, însă această potrivire perfectă în pronunțare nu implică neapărat și în primă instanță o schimbare a bazei de articulație (Philippide, 1927), din moment ce există și adaptări și deprinderi. Totodată, A. Philippide privește baza de articulație drept cauză a schimbărilor lingvistice, situația cîtorva indivizi asimilați în masa unui popor, în mijlocul căruia trăiesc, sau chiar a unor colectivități care și-au părăsit limba de baștină și au adoptat limba străinilor cu care se află în continuu contact prezentîndu-se cu totul diferit 
de cea a popoarelor anteromane care au adaptat limba latină potrivit (și la ) bazelor lor de articulație. De altfel, exemplele aduse în discuție de către F. de Saussure și de către S. Pușcariu nu arată că „celții, iberii, tracii, ilirii nu vor fi dezvoltat, din cauza bazei lor de articulație și a bazei lor psihologice proprii, nuanțe dialectale chiar din momentul cînd își vor fi păăsit limbile de baștină și vor fi adoptat pe cea latinească” (Philippide, 1927).

Baza de articulație nu trebuie confundată cu capacitatea sau incapacitatea vorbitorilor de a pronunța în mod absolut un sunet. În acest sens, nimic nu împiedică pe un african, cu o conformație proprie şi diferită a organelor articulatorii, să poată rosti sunetele și mai ales coarticulațiile limbii franceze, germane etc. la fel de bine precum vorbitorii indigeni, întrucît cu instrumente diferite se pot pronunța exact aceleași sunete (Philippide, 1927). Baza de articulaţie nu se manifestă doar prin posibilitatea sau imposibilitatea de a rosti un sunet oarecare, ci și prin preferința de a articula un sunet sau altul (Ivănescu, 1984), în mod firesc, chipul de a fi al acesteia într-un fel moștenindu-se prin comunitate și în altul dobîndindu-se prin acumulare de trăsături dobîndite pe parcursul vieții.

Interesant dar semnificativ pentru astfel de critici este că, pe de o parte, F. de Saussure respinge baza de articulație ca pe un dat natural inacceptabil prin consecințe și greu de lămurit sub aspect științific, dar, pe de altă parte, susține că există deprinderi, pe care le numește „predispoziții diferite” (Saussure, 1997), în fapt, susținînd astfel existența unui dat predeterminat. Oricum ar fi, indiferent de ceea ce declară, astfel de poziții indică neînțelegerea faptului că materia nu este imuabilă, că, în devenirea ei, pare a tinde continuu către echilibru, și că dominanta nu este elementul și nici sistemul, ci mediul în sens larg. De aceea, baza de articulație nu presupune imposibilități și ierarhii, ci constrîngeri vremelnice și devenire prin adaptarea la mediu.

Se cuvine observat, totodată, că, în condițiile în care lingvistica din vremea lui F. de Saussure emisese felurite teorii asupra „superiorităţii” unor limbi asupra altora și încerca unele ierarhizări, complet neștiințifice și fără temei, întîmpinarea lui F. de Saussure este scuzabilă și de înţeles, ceea ce nu mai poate fi tratat cu aceeași înţelegere fiind perpetuarea acestei asocieri eronate ${ }^{17}$.

3.3. După ce identifică voința cu scopul și arată că aparatul fonator este singurul element fizic și material din limbă, K. Vossler vede cauza schimbării sunetelor exclusiv în psihicul uman, în baza psihologică, prin care el înțelege, în primul rînd, reprezentările cognitive și afectul, care însoțesc aceste reprezentări. Potrivit lui K. Vossler, reprezentările cognitive ale sunetelor sînt mereu altele, se schimbă și diferă astfel încît schimbările calitative în reprezentarea unui sunet se petrec fără vreo intervenție din partea sunetelor fizice ocazionale, doar printr-un salt calitativ produs în minte, adică prin faptul că reprezentarea își schimbă prin ea însăși firea, această fire schimbată în conștiința vorbitorului fiind copiată de sunetul ocazional. Totodată, K. Vossler consideră că la schimbare concură, mai mult sau mai puțin, puzderia de elemente pe care, de altfel, lingviștii le-au avut în vedere dintotdeauna (de la dispoziția de moment, trecînd prin etapele de transmitere a limbii de la o generație la alta și pînă la modă) (Philippide, 1927).

Privitor la eliminarea factorului fizic, A. Philippide întîmpină idealismul lui Vossler cu o replică foarte nimerită: „de ce acel lucru care produce sunetele nu și le-ar putea schimba?” (Philippide, 1927), iar în ceea ce privește modalitatea de formare a reprezentărilor și a conceptelor, A. Philippide afirmă: „după cum cunoștința despre lup și cunoștința despre galben nu le pot căpăta, pînă ce n-oi vedea lupul și galbenul în lumea fizică, tot așa nici cunoștința despre ă în cuvîntul tacere n-am s-o pot căpăta pînă ce nu voi auzi pe $\breve{a}$ din lumea fizică, ca sunet fizic al vorbirii ocazionale" (Philippide, 1927). Cu alte cuvinte, psihicul nu poate institui o realitate obiectuală și/sau acustică și nici nu o poate preface în alta, el poate

\footnotetext{
${ }^{17}$ De aici mai decurge un aspect important pentru dezvoltarea științei, deseori observat și arătat, dar des ignorat. Fiind determinate de factori de mediu, în sens larg, concepțiile pot răspunde unor nevoi concrete și actuale, uneori putînd deveni repere pentru cercetarea și formarea concepțiilor viitoare. Dincolo de faptul că, adesea, aceste rezultate pot fi eronate, caracterul lor marcat de mediul spațio-temporal, conjunctural etc. face în mod necesar ca respectivele concepții să devină caduce, lucru pe care cercetarea are datoria de a-l observa, acționînd în consecință prin periodice verificări, reconsiderări și acomodări la noile realități.
} 
numai substitui o reprezentare cu o altă reprezentare a unei realităţi existente în lumea materială. Căci, dacă se admite că o reprezentare a unui sunet poate apărea fără ca acesta să fi existat în vorbire, este cu neputință să se arate cum poate acea reprezentare să le dea indicaţii organelor articulatoare să producă sunetele (schimbate) corespunzătoare în vorbirea ocazională (Philippide, 1927). Prin aceasta lingvistul ieșean se așează pe poziția senzualistă (Nibil est in intellectu quod non prius fuerit in sensu), cu lungă tradiție filozofică, adoptată, parțial și nuanțat de științele naturii, așezată la baza metodelor de cercetare științifică, programatic și sistematic, după R. Bacon. Concepția este bogat reprezentată în lingvistica vremii prin A. Schleicher și M. Müller, printre alții.

De altminteri, rolul afectului în schimbarea sunetelor ridică probleme. Probabil este adevărat că cele dintîi sunete ale vorbirii au luat fință în urma unor mișcări reflexe provocate de afecte, astfel încît o stare afectivă oarecare precede vorbirea ocazională, acest fapt fiind cauza pentru care s-a utilizat și modelat instrumentul trebuitor reproducerii sunetului, pus fiind în funcțiune într-un anumit fel (Philippide, 1927). Această „procedare primitivă”, în care sentimentul creează instrumentul și sunetele, nu mai poate acționa-decît cu unele excepții ${ }^{18}$ —în cadrul unei limbi deja formate care se schimbă deoarece sentimentul provoacă doar reproducerea instrumentului deja existent și nu poate decît să-l modifice puțin, în sensul că „sentimentele de excitare închid mai tare sunetele, cele de deprimare le deschid mai tare ori fac să înceteze vibrarea coardelor vocale" (Philippide, 1927). Pe de altă parte, sentimentul poate avea unele efecte asupra punerii în funcţiune într-un anumit fel a instrumentului, în sensul că provoacă variabilitate în timpul cît funcționează instrumentul (tempo), în amplitudinea vibrațiilor lui (accent expirator) şi în numărul vibraţiilor în unitatea de timp (accent muzical), ceea ce face ca sunetele să fie mai mult sau mai puțin energice, ca ele să aibă mai multă ori mai puțină putere de a rămîne neschimbate. Însă sentimentul nu creează accentele și durata înseși, ele fiind inerente sunetelor prin faptul producerii lor, existînd, deci, și independent de sentiment. Afectivităţii i se datorează doar variabilitatea accentelor și a duratei care este însă lipsită de constanță și de persistență în aceeași direcție (Philippide, 1927). Or, atunci cînd nu există persistență în aceeași direcție, nu se produce o schimbare efectivă a sunetului (adică o schimbare a timbrului), fiindcă deosebirile se învîrt în jurul aceluiași punct și se anihilează. În aceste condiții, reprezentările cognitive și complexul afectiv, adică ceea ce constituie în mare parte baza psibologică la Vossler, însoțesc sunetele articulate, dar fără forța necesară schimbării sunetelor (Philippide, 1927) ${ }^{19}$.

„Baza psihologică” este o sintagmă și un concept care apar la A. Philippide, la care chiar are o accepțiune mai largă decît la K. Vossler, prin bază psihologică lingvistul român înțelegînd „felul de a fi al psihicului ca intelect și sentiment" (Philippide, 1927), adică sufletul omenesc în integralitatea sa, cuprinzînd intelectul (gîndirea și cunoștințele, cultura), dar și afectele și voința ${ }^{20}$.

Totuşi, întîmpinarea lui K. Vossler diferă fundamental de cele anterior prezentate. Spre deosebire de ceilalți, lingvistul german nu are în vedere cauze de ordin ideologic, el plecînd de la o concepție filozofică asupra lumii. Eroarea sa este dată doar de reducționismul și exclusivismul practicat—întemeiat pe concepția sa filozofică-, prin care reduce totul la factorul psihic, pe care îl absolutizează, eliminînd factorul fizic. În fapt, limba nu apare și nu se constituie cu un scop sau ca urmare a unui scop, ci este un produs istoric al existenței și funcționării ființei umane, în cadrul social. Evoluînd, sistematizîndu-se și specializîndu-se, ea ajunge să fie conștientizată și să își găsească scopuri, însă acestea nu îi modifică radical esențele, aşa cum

\footnotetext{
${ }^{18}$ Unele rămășițe ale ei se mai găsesc în cuvintele onomatopeice și în procesul continuu de creare a interjecțiilor.

${ }^{19}$ Discuția despre direcțiile și constanța variațiilor este foarte complexă și bine reprezentată în domeniul științelor naturii, mai ales după apariția teoriei evoluționiste. Vom aborda această chestiune în partea a doua a studiului nostru.

${ }^{20}$ În concepția lingvistului român, baza psihologică reunește elemente ce țin de specificul etnic cu cele de ordin psihic, cultural, dar și elementul universal și formal, adică însuși actul de gîndire, comun întregii umanități, care este același în toate timpurile și la toate popoarele și care ar putea fi numit bază spirituală (Ivănescu, 1980, 1984).
} 
ființa vie nu-și poate modifica acizii nucleici din care provine, așa cum semnul lingvistic natural, deși se încarcă cu straturi socio-psihologice, cognitive, chiar autoreflexive, nu-și pierde fundamentele naturale.

Pentru a putea fi percepută deopotrivă în afara gîndirii, limba, ca instrument de comunicare a experiențelor, cunoștințelor, stărilor, ideilor etc., trebuie să recurgă la un sistem de semne de natură materială, acustică, realizat prin mișcarea organelor articulatorii ${ }^{21}$. Din moment ce sunetele (realitate fizică ce decurge din articulații) sînt determinate în natura lor de felul și de modul de funcționare a organelor articulatorii, este lesne de înțeles că și schimbările sunetelor sînt în esență materiale și că ele se impun psihicului în urma producerii lor fizice. Conștiința individului vorbitor le percepe și le interpretează. Chiar dacă s-ar admite că schimbările pornesc dintr-un impuls al psihicului, oricare ar fi acela, conștiința nu poate opera cu ceva ce nu s-a produs în mod fizic. Cu alte cuvinte, orice bază este materială, factorul psihic poate exercita influențe, dar nu poate determina materia la modul absolut. Așadar, dezvoltarea limbii nu poate fi privită izolat de baza ei materială, de determinările sale fizice, așa cum, ulterior, ea nu se poate detașa de baza ei psihică și spirituală și, în general, de ființa vorbitoare, din cadrul social și istoric în care se produce actul comunicării și cunoașterii prin limbă. A. Philippide crede în rolul bazei psihologice în configurarea fizionomiei particulare a unei limbi, dar arată că elementul individualizant al unei limbi este, înainte de toate, aspectul ei fonetic. Determinările psihice (afective, temperamentale) şi/sau cele cognitive și spirituale (modul de a gîndi, viziunea asupra lumii) nu sînt întotdeauna net deosebite de la un popor la altul, iar atunci cînd există diferențe incontestabile, acestea au repercusiuni vădite mai degrabă asupra structurării lexicului, morfologiei și a sintaxei, dar nu asupra sistemului fonetic al limbii respective (Philippide, 1927).

\section{Concluzii parţiale}

În vreme ce determinarea psiho-socială a limbii nu a fost contestată cu atîta asprime de către lingviștinici atunci cînd limba se studia exclusiv prin structurile ei lingvistice, cum procedează structuraliștii, în general一, determinarea fizică a limbii, prin felul de a fi al organelor articulatorii și prin funcționarea lor, s-a lovit deseori de dezaprobare din partea multora sau, în orice caz, ea a fost considerată ca fiind nesemnificativă ori proprie aservirii, comparativ cu alți factori.

Totuşi, existența unei baze de articulație care guvernează felul de a fi al unei limbi și schimbările acesteia, din punct de vedere fonetic, este destul de vădită atunci cînd o constatăm la nivel de trăsături generale. Ce-i drept, urmărirea ei în detalii, prezentarea prin descriere apar a fi destul de anevoioase. Însuși Philippide, care are meritul de a fi dezvoltat această teorie, neclarificată suficient de nici un alt învățat pînă la el, recunoaște neputința de a explica, în toată complexitatea lor, schimbările fonetice prin bazele de articulație, fapt care se reflectă și prin nevoia precizărilor terminologice sau privitoare la conținutul termenilor folosiţi.

\section{Bibliografie}

Anderson, S.R. (1985). Phonology in the Twentieth Century. Theories of Rules and Theories of Representations, The University of Chicago Press, Chicago.

Borissof, C.L. (2011). Basis of articulation and articulatory setting in pronunciation teaching: Focusing on English and Russian, dizertație master, Universitatea din Londra, [online].

Borissoff IATEFL = Borissoff, C., Basis of Articulation or Articulatory Setting?, IATEFL Pronunciation Special Interest Group Newsletter Issue 46, [online].

Coșeriu, E. (1992). Linguistic changes does not exist?, traducere de Emma Tămâianu, în „Cercetări de lingvistică”, anul XXXVII, nr. 1, p. 9-20.

Dessalles, J-L. (2007). Why We Talk. The Evolutionary Origins of Language, Oxford University Press, Oxford.

Dorogovtsev, S.N. \& Mendes, J.F.F. (2001). Language as an Evolving Word Web, în „Proceedings of The Royal Society B. Biological Sciences", vol. 268, nr. 1485, p. 2603, arXiv, Crossref.

\footnotetext{
${ }^{21}$ În fapt, este invers: acele mișcări de natură fizico-afectivă au devenit sistem de comunicare; ele premerg ,apariția limbii”.
} 
Drachman, G. (1973). Phonology and the basis of articulation, în „Sprache”, vol. 19, p. 1-19.

Dresher, B.E. (2016). Contrast in Phonology, 1867-1967: History and Development, în „Annual Review of Linguistics”, vol. 2, p. 53-73, Crossref.

Dressler, W. (1976). Fonologia naturale e cambio linguistico, în Simone, R., Vignuzzi, U. \& Ruggiero, G. (eds), Studi di fonetica e fonologia. Atti del convegno internazionale di studi, Padova 1 e 2 ottobre, 1973, Bulzoni, Roma, p. 273-283.

Falk, D. (1975). Comparative Anatomy of the Larynx in Man and the Chimpanzee: Implications for Language in Neanderthal, în „American Journal of Physical Anthropology”, vol. 43, nr. 1, p. 123-132, Crossref.

Falk, D. (2009). Finding our Tongues: Mothers, Infants and the Origins of Language, Basic Books, New York.

Francescato, G. (1968). Speech perception and the „basis of articulation”, in „Folia Linguistica”, vol. 2, nr. 3-4, p. 176-182, Crossref.

Gick, B., Wilson, I., Koch, K. \& Cook, C. (2004). Language-Specific Articulatory Settings: Evidence from Inter-Utterance Rest Position, în „Phonetica”, vol. 61, nr. 4, p. 220-233, [online], Crossref.

Ginneken, J. van (1933). La biologie de la base d'articulation, în „Psychologie du Langage”, Librairie Félix Alcan, Paris, p. 266320, [online].

Grammont, M. (1933). Traîté de phonétique, Ch. Delgrave, Paris.

Guion, S. G. (2003). The Vowel Systems of Quichua-Spanish Bilinguals. Age of Acquisition Effects on the Mutual Influence of the First and Second languages, în „Fonetica”, vol. 60, nr. 2, p. 98-128, Crossref.

Hinde, R. A. (1977). Le basi biologiche del comportamento sociale umano, Zanichelli, Bologna.

Honikman, B. (1964). Articulatory Settings, în Abercrombie, D., Fry, D. B., MacCarthy, P. A.D., Scott, N.C. \& Trim, J.L.M. (eds), In Honour of Daniel Jones, Longman, Londra, p. 73-84, [online].

Ivănescu, G. (1972). Storia delle parlate popolari e storia delle lingue letterarie, în „Philologica”, vol. II, p. 5-25.

Ivănescu, G. (1980). Istoria limbii române (în special Preliminarii), Editura Junimea, Iaşi.

Ivănescu, G. (1983). Lingvistică generală și românească, ediție de Vasile Șerban și Vasile D. Țâra, Editura Facla, Timișoara.

Ivănescu, G. (1984). Alexandru Philippide - Teoretician al limbajului, studiu introductiv la Philippide (1984), p. IX-XLVI.

Ivănescu, G. (1998). Studii de istoria limbii române literare, ediție îngrijită și prefață de Al. Andriescu, Editura Junimea, Iaşi.

Jakobson, R. (1973). Main Trends in the Science of Language, Allen \& Unwin, London.

Jenkins, L. (1999). Biolinguistics. Exploring the Biology of language, Cambridge University Press, Cambridge.

Jenner, B. (2001). Genealogies of Articulatory Settings: Genealogies of an idea, în „Historiographia Linguistica”, vol. 28, nr. 1-2, p. 121-141, Crossref.

Kedrova, G. \& Borissoff, C.L. (2013). The Concept of 'Basis of Articulation' in Russia in the First Half of the 20th Century, in „Historiographia Linguistica”, vol. 40, nr. 1, p. 151-197, Crossref.

Kellog, V.L. (1907). Darwinism to-day, H. Holt and Company, New York, [online].

Koerner, E. F. K. (2004). Essays in the History of Linguistics, John Benjamins, Amsterdam - Philadelphia, Crossref.

Kovács, F. (1971). Linguistic Structures and Linguistic Laws, Akadémiai Kiadó, Budapest.

Lenneberg, E.H. (1971). Fondamente biologici del linguaggio, Universale Bollati Boringhieri, Torino.

Lieberman, Ph. (1984). The Biology and Evolution of Language, Harvardy University Press, Cambridge, MA.

Lieberman, Ph. (2006). Toward an Evolutionary Biology of Language, Harvard University Press, Cambridge, MA.

Lowie, W.M. \& Bultena, S. (2007). Articulatory settings and the dynamics of second language speech production, în Maidman, J. (ed.), ,Proceedings of the PTLC 2007 Phonetics Teaching \& Learning Conference, London, UCL, aug. 24-26, 2007”, Londra, [online].

MacNeilage P. (2008). The Origin of Speech, Oxford University Press, Oxford.

Meillet, A. (1925). La méthode comparative en linguistique historique, H. Aschehoug, Oslo.

Mennen, I., Scobbie, M.J., Leeuw, E. de, Schaeffler, S. \& Schaeffler, F. (2010). Measuring language-specific phonetic settings, în „Second Language Research”, vol. 26, nr. 1, p. 13-41, [online], Crossref.

Oliveira, V.M. de, Gomes, M. A. F. \& Tsang, I. R. (2006). Theoretical model for the evolution of the linguistic diversity, în „Physica A: Statistical Mechanics and its Applications", vol. 361, nr. 1, p. 361-370, Crossref.

Osborn, H.F. (2012). Darwin's Theory of Evolution by the Selection of Minor Saltations, în „The American Naturalist”, vol. XLVI, nr. 542, 1 febr., p. 76-82, Crossref.

Oyama, S. (2015). Sustainable Development: Living with Systems, în Earth, Life, and System: Evolution and Ecology On a Gaian Planet, Fordham University, New York, p. 203-224.

Philippide, A. (1894). Istoria limbii române, vol. I, Principii de istoria limbii, Tipografia Națională, Iași.

Philippide, A. (1914). Introducere in știința limbii (reprodus în Philippide, 1984, p. 239-284).

Philippide, A. (1927). Originea romînilor, vol. II, Ce spun limbile română şi albaneză, Tipografia „Viața Românească”, Iaşi, §268, nota, p. 246-309; s-a consultat și ediția din 2016, ed. Roxana Vieru.

Philippide, A. (1984). Opere alese. Teoria limbii, editate de G. Ivănescu și Carmen-Gabriela Pamfil, cu un studiu introductiv și comentarii de G. Ivănescu, Editura Academiei, București; s-a consultat și cap. XII, Învățăminte trase din istoria sunetelor limbii române pentru originea Rominilor, p. 341-398.

Pușcariu, S. (1937). Études de linguistique roumaine, Georg Olms Verlag, Cluj - București.

Pușcariu, S. (1976). Limba română, vol. I, Privire generală, ediție, note, bibliografie, de Magdalena Vulpe și Ilie Dan, Editura 
Academiei, București.

Pușcariu, S. (1994). Limba română, vol. II, Rostirea, ediție îngrijită de Magdalena Vulpe, Editura Academiei, București.

Saussure, F. de (1997). Corso di linguistica generale, Introduzione, traduzione e commento di Tullio Di Mauro, Laterza, Roma - Bari.

Selinker, L. (1972). Interlanguage, în „International Review of Applied Linguistics”, vol. 10, nr. 1-4, p. 209-232, Crossref.

Thomason, S. G. \& Kaufman, T. (1988). Language Contact, Creolisation, and Genetic Linguistics, University of California Press, Berkeley, CA.

Trout, J.D. (2001). The biological basis of speech: What to infer from talking to the animals, în „Psychological Review”, vol. 108, nr. 3, p. 523-549, Crossref

Vargha-Khadem, F., Watkins, K.E., Price, K.J., Ashburner, J., Alcock, K.J., Connelly, A., Franckowiak, R.S.J., Friston, K.J., Pembrey, M.E., Mîshkin, M., Gadian, D. G. \& Passingham, R.E. (1998). Neural basis of an inherited speech and language disorder, „Proceedings of the National Acadademy of Sciences of the USA”, vol. 95, p. 12695-12700, Crossref.

Wartburg, W. von (1962). Problémes et méthodes de la linguistique, Presses Universitaires de France, Paris.

Wechssler, E. (1900). Gibt es Lautgesetze?, Niemeyer, Halle.

Wilson I. \& Gick B. (2006). Articulatory Settings of French \& English Monolinguals \& Bilinguals, „The Journal of the Acoustical Society of America”, vol. 120, nr. 5, p. 3295, [online], Crossref. 